\title{
EFFECT OF STORAGE PERIOD ON FERMENTATION POTENTIAL OF BACILLUS SUBTILIS A2
}

\author{
Ibrahim, T.A., Agbaje, R.B., Orungbemi, O.O. and Ajimuda, A.M \\ Department of Food Science and Technology, \\ Rufus Giwa Polytechnic, Owo, Ondo State, Nigeria
}

\begin{abstract}
Bacillus subtilis A2 stored over a period of time $(15,30$ and 45days) was used as starter culture to ferment African locust bean seeds to produce iru. The proximate composition and the sensory attributes of the fermented African locust bean seeds (iru) were determined using standard methods. The result of proximate composition showed that the protein value ranged from 38.54 $41.63 \%$, ash $(2.32-3.38 \%)$, fibre $(4.43-5.53 \%)$, fat $(18.78-19.62 \%)$, moisture $(11.74-12.00 \%)$ and total carbohydrate (by different) $(20.00$ $22.97 \%$ ). The results of the proximate composition revealed that the storage period had little or no effect on the fermentation potential of the starter culture when compared with the control with 24 hours old starter culture. The sensory evaluation of all the samples indicates that the use of the starter culture for the production of iru gave production that is acceptable in all the tested parameters.
\end{abstract}

\section{INTRODUCTION}

Fermented vegetable protein seeds used for condiments constitute a significant proportion of African diets where they serve as flavoursome and culinary components in various dishes [Achi, 2005]. The vegetable protein seed used in production in West

Africa include African locus bean (Parkia Biglobosa (Jacq. Benth)), melon seeds (Citrullus vulgaris (schrad)), castor oil seeds (Ricinus communis). Fluted pumpkin seeds (Telfaria occidentalis), African yam bean (Stenophylis stenocarpa), cotton seeds (Gossypium hirsitium (L.)), roselli seeds (Hibiscus sabdariffa) and baobab seeds (Adansonia digitata (L.)) [Onoba et al.,2008, Parkouda et al., 2010]. They include iru or dawadawa in Nigeria and Ghana; soumbala, bikalga, and maari in Burkinafaso; afitin and sonru in Benin Republic; netetou in Senegal; kinda in Sierra Leone; dawadawa botso in Niger
Republic; datou in Mali; mbuja in Cameroon and furundu in Sudan [Parkouda et al., 2010].

However, the vegetable seeds used for the production of these condiments differ considerably from one region to another [Achi, 2005]. Nonetheless, the production process for iru are generally characterized by spontaneous solid substrate alkaline fermentation with increase in $\mathrm{pH}$ because of extensive hydrolysis of the proteins into peptides, amino acids and ammonia, which favours the dominance of Bacillus spp. As the fermenting organisms [Kurs et al., 2000.,Sarkar et al., 2020]. The production of iru locally is also carried out in exclusive uncontrollable environmental conditions thereby yielding products with variation in quality and organoleptic properties [Sanni, 1993 and Steinkraus, 1997]. This necessitates the need for the development of appropriate starter cultures to initiate fermentation for the production of consistent products with acceptable qualities.

The processing operations of African locust bean to produce iru involve cleaning and sorting, boiling, dehulling, and fermentation ambient temperature [Odunfa, 1985]. Investigations on the microbiology of iru using selective isolation and cultivation based on traditional culture-dependent methods including the biochemical changes that occur during fermentation have been documented [ Odunfa, 1985, Omafuube, 2004]. These techniques often fail to account for minor microbial populations; stressed and injured cells that ar present in low number [Kesmen et al., 2012] and have been observed not to give a complete representation of food microbial communities [ Kesmen et al., 2012]. Also, they are bias, unreliable and lack accurate detection of population dynamics and microbial diversity [Amann et al., 1995, Jany and Barbier, 2008].To determine the effect of storage period on the fermentation potential of Bacillus subtilis A2 . 


\section{International Journal of Engineering Applied Sciences and Technology, 2019 \\ Vol. 4, Issue 7, ISSN No. 2455-2143, Pages 292-296 \\ Published Online November 2019 in IJEAST (http://www.ijeast.com)}

\section{MATERIALS AND METHODS}

\section{Source and Preparation of Locust bean Seeds for} Fermentation

The African locust bean seeds (Parkia biglobosa) used for the laboratory study was bought from Oja Oba, in Ado Ekiti, Ekiti State. The reagents and equipment employed in the process of production and analysis of the iru was obtained from the laboratory of Microbiology Laboratory of Department of Food Science and Technology, Rufus Giwa Plytechnic, Owo, Ondo State.The Parkia biglobosa seeds were weighed, boiled and dehulled to wash off the testa. The seeds were steamed again with little water and then drained aseptically.

\section{Preparation of Starter Cultures}

Previously isolated Bacillus subtilis A2 was obtained from the Department of Microbiology, Ekiti State University, Ado Ekiti activated by taking some of the bacteria with a sterilized wire loop and mixing it with a freshly prepared nutrient broth and incubated for 15 , 30 and 45 days before been introduced into the fermenting medium for iru production. A 24 hours old culture serves as control.

Proximate Composition
The proximate composition of samples was carried out using the methods described by the Association of Official Analytical Chemist [AOAC, 2005].The parameters determined were crude protein, crude ash, crude fibre, crude fat and carbohydrates (by difference).

\section{Sensory Evaluation of the Iru Samples}

Sensory evaluation was carried out using semi trained taste panelists to assess the sensory attribute (colour, aroma, taste, texture and overall acceptability) of the produced iru. The panelists were selected randomly cutting across students and workers of the Polytechnic community which include people who are used to eating iru and those who are not used to it. The samples were presented in coded identical plates. The panelists were instructed to rate the sample for the parameters based on a 9- point hedonic scale ranging from 9-liked extremely to 1-disliked extremely. The raw scores was statistically analyze using the method described by [Ihekoronye and Ngoddy, 1995].

\section{Statistical analysis}

Data obtained from the study of the sensory evaluation will be subjected to Analysis of Variance (ANOVA) and the means will be separated using Fisher LSD and judged significantly different at $95 \%$ confidence level (i.e. $\mathrm{P}<0.05)$.

\section{Results and Discussion}

Table 1: Proximate compositions of African locust bean seeds fermented with B. subtilis A2

\begin{tabular}{lllllll}
\hline Sample & Protein & Ash & Crude fibre & Fat & Moisture & Carbohydrate \\
\hline A & 38.34 & 3.38 & 5.53 & 18.78 & 11.6 & 22.97 \\
B & 40.97 & 2.42 & 4.69 & 18.96 & 11.9 & 21.06 \\
C & 41.63 & 2.32 & 4.43 & 19.62 & 12.00 & 20.00 \\
\hline
\end{tabular}

Key: Sample A: $\quad$ African Locust Bean Seeds fermented with 15 days old culture

Sample B: $\quad$ African Locust Bean Seed fermented with 30 days old culture

Sample C: $\quad$ African Locust Bean Seeds fermented with 45 days old culture

Table 2: Sensory evaluation of African locust bean seeds fermented B. subtilis A2

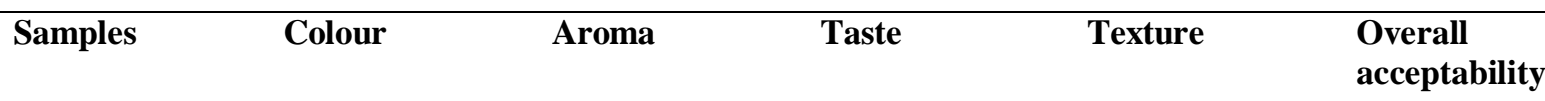




\section{International Journal of Engineering Applied Sciences and Technology, 2019 Vol. 4, Issue 7, ISSN No. 2455-2143, Pages 292-296 \\ Published Online November 2019 in IJEAST (http://www.ijeast.com)}

\begin{tabular}{llllll}
\hline A & 7.60 & 7.50 & 7.34 & 8.00 & 7.00 \\
B & 8.50 & 7.80 & 9.02 & 8.80 & 9.23 \\
C & 3.62 & 6.32 & 5.61 & 8.30 & 5.34 \\
\hline
\end{tabular}

Key: Sample A: African Locust Bean Seeds fermented with 15 days old culture

Sample B: $\quad$ African Locust Bean Seed fermented with 30 days old culture

Sample C: $\quad$ African Locust Bean Seeds fermented with 45 days old culture

Table 1 showed the effect of storage period on the performance of starter culture $B$. subtilis A2 in relation to proximate composition of African locust bean (iru). The protein content ranged from $38.34-41.63$, ash 2.32 - 3.38, crude fibre 4.43-5.53, crude fat $23.78-$ 26.62 and total carbohydrate $20-22.97 \%$. The percentage moisture content ranges from 11.00-12.00. The protein content of iru produced by the preserved starter culture could be generally considered very rich in protein $(38.34-41-63 \%)$. The high amount of protein in the iru samples may be due to the ability of the starter culture to digest protein and change the small size peptide as well as functional properties [Awor, 2008]. Obviously, report, fermentation of legumes and cereal can increase in the amino acid content [9]. The increase in the protein content of fermented products is excepted of the fermentation organisms (especially Bacillus sp.) even stored over a period of time that are known to be proteolytic and possess high level of free acid. This implies that one of the desirable effects of the fermentation process is the increment in the protein content.

The increase observed in the moisture content of the fermented affirm locust bean seeds using the preserved/stored Bacillus subtilis A2 after fermentation is in line with the report of [Anti and Ibrahim, 1986, Omodara ] who reported an increase in the moisture content o bambara nuts after fermentation. This result differs for the report of [Enujiugba and Badejo, 2007] who reported a decrease in the moisture content of a African locust bean after 72hours of fermentation. The crude fibre of the iru samples were relatively ions but less than $8.8 \%$ value reported for iru samples by [Enujiugba and Badejo, 2007] 10\% for soybean [Omafuube et al., 2004] but higher than $3.6 \%$ value reported for cowpea [Eka, 1990]. Boiling and Dehulling the African locust beans seed required it's crude fibre. This pattern agrees with the observation of [Latunde-Dada, 2000]. At the end of the boiling process, the boil water of the African locust beans was more viscours than it was at the beginning of the process. This is an indication of the presence of mucilaginous material in the boil water, which willed explain in part the reduction of the crude fibre content of the African locust been seeds on boiling.

The ash content of the iru samples decreased with the storage time of the starter culture. The value reported for African locust bean agrees favourably with $5.1 \%$ (only for iru sample fermented with 15days stored B.subtilis A2 as reported by [Adebayo et al., 2010]. Boling and soaking in water and dehulling of locust bean led to a loss of about $40 \%$ ash. This mean that the percentage of the total minerals reside in the hull of the seed or leached during processing [Latunde-Dada, 2000]. The fat content of the iru samples showed that lipase activity is low in fermentation African locust bean seed so some short chain fat are known to enhance the flour of food. This may have some contribution to the descended aroma that the condiment imparts in soup [Oyeyiola,1988]. On the other hand, the carbohydrate content reduces as the days of storage of the starter culture increase. The main substrate in the sample that serves as food (energy) for the fermenting organism is the carbohydrates.

Table 2 shows the sensory evaluation of African locust bean seeds fermented which preserved B.subtilis A2 culture. The colour ranged from $3.62-$ 8.50 , aroma $6.32-7.80$, taste $5.61-9.02$, texture 8.00 -8.80 and the overall acceptance $5.35-9.23$. All the iru samples produced was accepted in term of colour (except sample C) aroma, taste, texture and overall acceptability (except sample C). The work agrees with the work of [Omodara and Aderibigbe, 2013] that noted that the sensory attributes of African locust bean has been widely accepted mostly those produced by starter culture.

\section{CONCLUSION}

From this work, it has been confirmed that storage had little or no effect on Bacillus subtilis A2 


\section{International Journal of Engineering Applied Sciences and Technology, 2019 \\ Vol. 4, Issue 7, ISSN No. 2455-2143, Pages 292-296 \\ Published Online November 2019 in IJEAST (http://www.ijeast.com)}

used as starter culture and the iru produced were desirable nutritionally since the process increases the nutrients. The local use of the condiment is expected to increase the intake of the essential daily allowable nutrients of the body.

\section{REFERENCES}

1. Achi, O.K (2005). Traditional fermented protein condiments in Nigeria. African Journal of Biotechnology, 4(13), 1612-1621.

2. Onoba L.I.I. Parkouda, C. Diawara, B. Scotti, C. and Varnam, A.H. (2008). Identification of Bacillus spp., from fermented seeds of Hibiscus sabdariffa: J. Appl. Microbol. 104, 122-131.

3. Parkouda C. Thorsen, L. compaore, C.S., Nulsen, D.S., Tano Debrah, K. Jensen, J.S.(2010). Microorganisms associated with maari, a baobab seed fermented product. Int. J. food Microbiol. 142, 292-301.

4. Kurs, J.L. Van laeken, A.E.A., Rombouts, F.M. and Nout, M.J. R. (2000). In vitro digestibility of Bacillus fermented soybean. Int. J. Food Microbol. 60, 163-169.

5. Sarkar, P.K. Hasenack B., and Nout, M.J.R. (2002). Diversity and functionality of Bacillus and related general isolated form spontaneously fermented soybeans (Indian Kinema) and locust beans (soumbala). Int. J. Food Microbiol. 77, 175-186.

6. Sanni, A. I. (1993). The need for process optimization of African fermented foods and beverages. Int. J. food microbial. 18,85-95.

7. Steinkraus, K.H. (1997). Classification of fermented foods. Worldwide review of household fermentation techniques. Food Control 8, 311-317.

8. Odunfa S.A. (1985). Identification of microorganisms associate to iru fermentation. Journal of Plant Foods 2:245-250.

9.Omafuube, B.O. Olumuyiwa, S. Falade, B.A., Osuntogun, Steve, R.A. and Adewusi. (2004). Chemical and biochemical changes in African locust beans (Parkia biglobosa) and melon (Citrullus vulgaris) seed during fermentation to condiments, Parkston Journal of Nutrition, 3(3), 140-145.
10. Kesmen, Z. Yetiman, A.E. Gulluce, A., Kacmz, N., Sagdic, O., Cetin, B., (2012). Combination of culture-independent molecular methods for the determination of lactic microbiota in sucuk. Int. J. food Microbiol. 153, 428-435.

11. Amann, R.I.Ludwig, W. and Schleifer, K.H. (1995). Phylogenetic identification and in situ detection of individual microbial cells without cultivation. Microbial. Rev. 59, 143169.

12.Hugenhottz, P. goebbel, B.M. and Pace, N.R. (1998). Impact of culture independent studies on the emerging phylogenetic view of bacterial diversity. J. Bacteriol. 180, 47654774.

13.Jany, J.L. and Barbier, G. (2008). Cultureindependent methods for identifying microbial communities in cheese. Food Microbial. 25, 839-848.

14. Association of Official Analytical Chemists (A.O.A.C) (2005). Official Methods of Analysis. 19th Edition. Washington, DC., USA.

15.Ihekoronye, I.A and P.O.Ngoddy (1995). Integrated Food Science and Technology for the Tropics. Macmillan publishers, London, pp.235-230.

16.Aworh, O.C. (2008). The role of traditional food processing technologies in National Development: The West African experience. Journal of International Union of Science and Technology. 1-18.

17. Antai, S.P., Ibrahim, M.H. (1986). Microorganisms associated with African locust bean (Parkia filicoidea welus) fermentation for iru production. Journal of Applied Bacteriology, $61: 145-148$

18.Omodara. T.R and Aderibigbe E.T. (2013). Effect of the starter culture of the quality of fermented Parkia biglobosa. International Journal of Biotechnology, 3(4), 33-40.

19.Enujiugha V.N., Bdejo A.A. (2007). Cultural alteration for the improvement of Bacillus subtilis in the fermentation of African oil bean seeds (Pentadethra macrophylla benth). Journal of Applied Tropical Agriculture, :711. 


\section{International Journal of Engineering Applied Sciences and Technology, 2019 \\ Vol. 4, Issue 7, ISSN No. 2455-2143, Pages 292-296 \\ Published Online November 2019 in IJEAST (http://www.ijeast.com)}

20. Eka, O.U. (1990). Effect of fermentation on the nutrients status locust beans. Journal of Food Chemistry 5, 305-308.

21. Latunde-Dada, G. (2000). Fermented foods and cottage industries in Nigeria. Journal of Food Science, Pp. 20, 1-330.

22.Adebayo, G.B; Otunba G.A. Ajao, T.A (2010). Physiochemical, microbiological and sensory characteristic of Kunu prepared from millet, maize and guinea corn and stored at selected temperatures. Advanced Journal of Food Science and Technology. 2(1), 41-46.

23. Oyeyiola, G.P (1988). Microbiology of iru pete and iru woro obtained from local producers. MIRCEN J. 4, 439-445. 